\title{
EVALUASI KALIBRASI TRANDUSER RTD PT100 DAN TERMOKOPEL TYPE K
}

\author{
Sumarkantini \\ Program Studi Teknik Elektro FT UNPAM \\ JIn. Puspitek Raya No 11 Buaran, Tangerang Selatan 15310 INDONESIA \\ Email :dosen01695@unpam.ac.id
}

\begin{abstract}
ABSTRAK
Kalibrasi temperatur berupa PT100 maupun thermocouple dapat menggunakan metode perbandingan maupun simulasi. Metode perbandingan digunakan dengan cara membandingkan kalibrator standar berupa es batu maupun air mendidih terhadap indikator digital controller E5EK Omron. Data pengukuran temperatur dihitung melalui ketidakpastian standar, ketidakpastian master, ketidakpastian gabungan, dan ketidakpastian terentang. Hasil data pengukuran dibuat simulasi dengan manipulasi data pada indikator digital controller E5EK Omron. Sehingga pada PT100 dapat membuktikan bahwa pengukuran suhu 0 sampai dengan 100, menunjukkan Ohm pada PT100 meranjak naik setiap kenaikan suhu pada air sebesar $0,0385 \Omega / 1{ }^{\circ} \mathrm{C}$ dengan ketidakpastian sebesar $0,094 \Omega / 1{ }^{\circ} \mathrm{C}$ ( tabel 4.1 ). Dan pada pengukuran Termokopel Type K pada kalibrasi sendiri dapat menghasilkan yang mendekati hasil yang sudah dikalibrasi dan mendapakan koreksi / ketidakpastian rata - rata $0.09 \mathrm{~V} / 10^{\circ} \mathrm{C}$.
\end{abstract}

Kata Kunci : Alat, Pengukuran, Sonsor, Instrumen.

\begin{abstract}
Temperature Calibration of PT100 and Thermocouple. The method of comparison used by comparing the calibrator standard form of ice cube sand boiling water to E5EK Omron controllers digital indicators. Temperature measurement data is calculated through a standard uncertainty, uncertainty master, uncertainty and uncertainty combined outstretched. Simulation results of the measurement data created by the manipulation of data on indicators digital controller E5EK Omron.So that the PT100 can prove that the measurement temperature of 10 to 100, indicating the PT100 Ohm meranjak up every rise in temperature in water of $0,0385 \Omega / 1{ }^{\circ} \mathrm{C}$ with an uncertainty of $0,0094 \Omega / 10^{\circ} \mathrm{C}$. And the Type $K$ thermocouple measurements to the calibration itself can produce close results already calibrated and obtain correction / uncertainty average $0,09 \mathrm{~V} / 10^{\circ} \mathrm{C}$.
\end{abstract}

Keywords:Tool, Measurement, Sonsor, Instruments.

\section{PENDAHULUAN}

Setiap Instrumen Alat Ukur / sensor sebelum digunakan atau setelah digunakan pada periode tertentu ( 6 bulan atau 12 bulan), harus dilakukan pengukuran dan dikalibrasi sesuai standar nasional ataupun internasional.

Sensor merupakan perangkat input dan "mata" dalam sebuah proses industri untuk menghasilkan produk yang berkualitas, oleh karena sensor harus memiliki keakuratan dalam pembacaan, sehingga perlu dipelihara untuk mendapatkan umur (life time) yang panjang. Sensor temperatur pada Thermocouple ataupun PT-100, banyak digunakan dalam proses industri sebagai "peraba" yang menggunakan mesin pemanas, sebagai alat ukur temperatur supaya system tetap stabil. Dalam penelitian ini penulis berupaya untuk mewujudkan kegiatan praktikum, yaitu membuat evaluasi kalibrasi Tranduser RTD dan Termokopel type $K$, yang diharapkan dapat bermanfaat untuk digunakan oleh 
mahasiswa saat melakukan praktikum. Penulis dalam penelitian ini akan membahas tentang Evaluasi Sistem Kalibrasi Tranduser RTD dan Termokopel type $K$.

\section{TEORI}

\section{Teori Dasar Kalibrasi}

Kalibrasi adalah suatu kegiatan untuk menentukan kebenaran kovensional nilai penunjukkan alat ukur dan bahan ukur. Pelaksanaan kalibrasi dilakukan dengan cara membandingkan alat ukur dan bahan ukur yang akan dikalibrasi terhadap standar ukurnya yang mampu telusur (traceable) ke standar Nasional dan atau Internasional. Sedangkan tujuan dengan kalibrasi dapat ditentukan deviasi kebenaran konvensional nilai penunjukkan suatu alat ukur, atau deviasi dimensi nominal yang seharusnya suatu bahan ukur. Manfaat dengan kalibrasi kondisi alat ukur dan bahan ukur dapat dijaga tetap sesuai dengan spesifikasinya. Semua jenis alat ukur pelu dikalibrasi, baik alat ukur besaran dasar (panjang, massa, waktu, arus listrik, suhu, jumlah zat, intensitas cahaya), luas, isi, kecepatan, tekanan, gaya, frekuensi, energi, gaya dan sebagainya. Bila suatu alat ukur termasuk katagori legal, maka periode kalibrasinya telah ditentukan, kalibrasinya tergantung pada keperluan dan frekuensi penggunaanya. Beberapa contoh periode kalibrasi untuk beberapa instrument ukur tertentu:
a) Thermocouple : 2 bulan
b) Thermocontroller : 12 bulan
c) Hygrometer :6 bulan
d) Micrometer : 3 bulan
e) Vernier caliper : 12 bulan
f) Gauge block : 24 bulan
g) Profile proyektor : 12 bulan

Analisa ketidakpastian.

Komponen pengukuran dapat dibagi menjadi beberapa kelompok standar atau acuan yaitu benda ukur, peralatan.Metode, lingkungan dan personil atau perilaku pengukuran. Ada dua jenis ketidakpastian pengukuran berdasarkan ISO Guide 17025 : 2005 yaitu ketidakpastian, tipe A dan tipe $B$ yang dibedakan menurut metode evaluasinya. Tipe A dievaluasi dengan menggunakan metoda statistik yang baku untuk menganalisis satu himpunan atau sejumlah himpunan pengukuran, dan mencakup jenis kesalahan yang disebut kesalahan acak. Kesalahan ini dicirikan oleh taksiran variasi atau simpangan baku, nilai rata-rata dan derajat kebebasan. Tipe $B$ dievaluasi dengan cara selain analisis statistik pada sejumlah pengamatan. Ketidakpastian ini mencakup kesalahan yang dicirikan oleh taksiran variasi atau simpangan baku, nilai rata-rata dan derajat kebebasan. Menghitung ketidakpastian pengukuran yang diuraikan dalam ISO Guide 17025 : 2005 yang mencakup langkah-langkah evaluasi berupa:

a) Kenali faktor-faktor yang berkontribusi pada ketidakpastian.

b) Memasukkan Model matematik pengukuran.

c) Cari ketidakpastian baku masing-masing komponen.

Hitung ketidakpastian terentang dengan menggunakan faktor cakupan .

Sumber ketidakpastian yang paling berpengaruh dalam pengukuran adalah:

a) Daya baca alat ukur (skala atau tampilan alat).

b) Kebenaran nilai instrument acuan (sertifikasi kalibrasi).

c) Sebaran nilai-nilai pengukuran (pengukuran berulang).

Evaluasi ketidakpastian standar B

Evaluasi ketidakpastian tipe B dilakukan tidak dengan cara analisis statistik dari seri pengamatan pengukuran. Tetapi dievaluasi berdasarkan penetapan secara ilmiah menggunakan informasiinformasi yang tersedia seperti :

a) Data pengukuran sebelumnya.

b) Pengalaman.

c) Sifat-sifat material/instrument secara umum.

d) Spesifikasi pabrik.

e) Data dari laporan/sertifikasi kalibrasi.

f) Data yang diambil dari buku/literatur. Dalam mempertimbangkan ketidakpastian tipe $\mathrm{B}$ kita harus mengubah dari ketidakpastian yang dikutip ketidakpastian standar, dengan cara membagi dengan faktor pengali, adapun 
cara lain untuk mengubah ketidakpastian yang dikutip dari ketidakpastian standar adalah dengan cara membagi dengan suatu faktor yang bergantung pada distribusi probabilitas. Distribusi probabilitas rectangular.

Ketelitian pengukuran sebuah voltmeter $0,05 \%$, maka batas setengah interval adalah $0,005 \%$ dan ketidakpastian standar dihitung dengan rumus: $\mathrm{U}(\mathrm{v})=$ $0,005 \%$, distribusi probabilitas triangular. Distribusi ini merupakan model yang lebih baik, jika diketahui bahwa kebanyakan nilainilai pengukuran mendekati pusat (center) distribusi. Ketidakpastian standar dihitung dengan membagi setengah interval .

\section{Resistance Thermal Detector (RTD)}

Resistance Thermal Detector (RTD) atau dikenal dengan Detektor Temperatur Tahanan adalah sebuah alat yang digunakan untuk menentukan nilai atau besaran suatu temperatur/suhu dengan menggunakan elemen sensitif dari kawat platina, tembaga, atau nikel murni, yang memberikan nilai tahanan yang terbatas untuk masing-masing temperatur di dalam kisaran suhunya. Semakin panas benda tersebut, semakin besar atau semakin tinggi nilai tahanan listriknya, begitu juga sebaliknya. PT100 merupakan tipe RTD yang paling populer yang digunakan di industri.

Resistance Thermal Detector (RTD) atau dikenal dengan Detektor Temperatur Tahanan adalah sebuah alat yang digunakan untuk menentukan nilai atau besaran suatu temperatur/suhu dengan menggunakan elemen sensitif dari kawat platina, tembaga, atau nikel murni, yang memberikan nilai tahanan yang terbatas untuk masing-masing temperatur di dalam kisaran suhunya. Semakin panas benda tersebut, semakin besar atau semakin tinggi nilai tahanan listriknya, begitu juga sebaliknya. PT100 merupakan tipe RTD yang paling populer yang digunakan di industri.

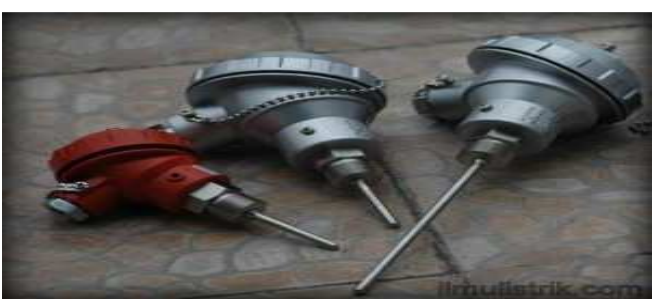

Gambar1.1 Tranduser RTD PT100.

Resistance Thermal Detectormerupakan sensor pasif, karena sensor ini membutuhkan energi dari luar. Elemen yang umum digunakan pada tahanan resistansi adalah kawat nikel, tembaga, dan platina murni yang dipasang dalam sebuah tabung guna untuk memproteksi terhadap kerusakan mekanis. Resistance Temperature Detector (PT100) digunakan pada kisaran suhu $-200{ }^{\circ} \mathrm{C}$ sampai dengan $650{ }^{\circ} \mathrm{C}$.

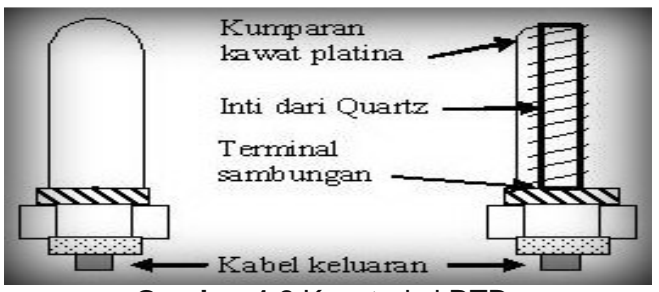

Gambar 1.2 Konstruksi RTD.

\section{Prinsip Kerja dari Tranduser RTD PT100}

Panas atau dingin yang dihasilkan berbanding lurus dengan tahanan dari jenis elemen logam platina yang ada pada sensor RTD, kemudian bentuk tahanan tersebut diterima oleh Tranduser kemudian tranduser merubahnya menjadi sinyal fisi dan mengirimnya ke TRC (Temperature Recorder Control).

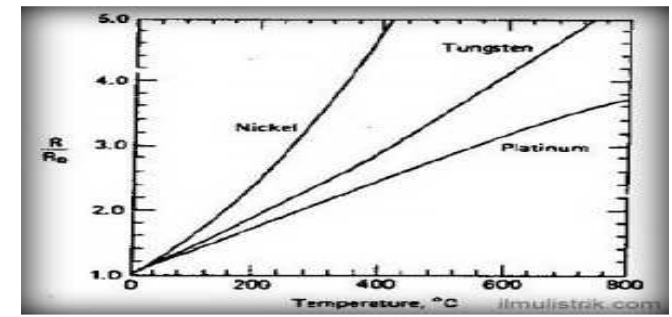

Grafik 1.3 Perbandingan resistansi temperatur untuk variasi RTD metal.

Kelebihan dan Kekurangan dari RTD (PT100)

Dalam penggunaannya, RTD (PT100) juga memiliki kelebihan dan kekurangan: 
- Ketelitiannya lebih tinggi dari pada termokopel.

- Stabil pada temperatur yang rendah, karena jenis logam platina lebih stabil dari pada jenis logam yang lainnya.

- Kemampuannya tidak akan terganggu pada kisaran suhu yang luas.

Kekurangan dari RTD (PT100) :

- Lebih mahal dari pada termokopel.

- Terpengaruh terhadap goncangan dan getaran.

- Respon waktu awal yang sedikit lama $(0,5 \mathrm{~s} / \mathrm{d} 5$ detik, tergantung kondisi penggunaannya).

- Jangkauan suhunya lebih rendah dari pada termokopel. RTD (PT100) mencapai suhu $650{ }^{\circ} \mathrm{C}$, sedangkan termokopel mencapai suhu $1700{ }^{\circ} \mathrm{C}$.

Tabel 1 Tipe dari Platinum Resistance Temperature Detector

\begin{tabular}{|c|c|c|c|c|c|c|}
\hline Tipe & $\begin{array}{c}\text { R100/ } \\
\text { R0 }\end{array}$ & Kelas & $\begin{array}{l}\text { Tingka } \\
\text { t Arus }\end{array}$ & & $\begin{array}{l}\text { Operating } \\
\text { Temperature } \\
\text { Range }\end{array}$ & $\begin{array}{c}\text { Lead } \\
\text { Wire } \\
\text { System }\end{array}$ \\
\hline \multirow{3}{*}{ PT100 } & \multirow{3}{*}{$\begin{array}{c}1,38 \\
5\end{array}$} & \multirow{3}{*}{$\begin{array}{l}\text { Kelas A } \\
\text { Kelas B }\end{array}$} & $1 \mathrm{~mA}$ & $\mathrm{~L}$ & $-200 \mathrm{~s} / \mathrm{d} 100^{\circ} \mathrm{C}$ & 2 - wire \\
\hline & & & $2 \mathrm{~mA}$ & $\mathrm{M}$ & $0 \mathrm{~s} / \mathrm{d} 350^{\circ} \mathrm{C}$ & 3 - wire \\
\hline & & & $5 \mathrm{~mA}$ & $\mathrm{H}$ & $0 \mathrm{~s} / \mathrm{d} 650^{\circ} \mathrm{C}$ & 4 - wire \\
\hline \multirow{3}{*}{ JPT100 } & \multirow{3}{*}{$\begin{array}{c}1,39 \\
16\end{array}$} & \multirow{3}{*}{$\begin{array}{l}\text { Kelas A } \\
\text { Kelas B }\end{array}$} & $1 \mathrm{~mA}$ & $\mathrm{~L}$ & $-200 \mathrm{~s} / \mathrm{d} 100^{\circ} \mathrm{C}$ & 2 - wire \\
\hline & & & $2 \mathrm{~mA}$ & M & $0 \mathrm{~s} / \mathrm{d} 350^{\circ} \mathrm{C}$ & 3 - wire \\
\hline & & & $5 \mathrm{~mA}$ & $\mathrm{H}$ & $0 \mathrm{~s} / \mathrm{d} 650^{\circ} \mathrm{C}$ & 4 - wire \\
\hline
\end{tabular}

Resistance Thermal Detector (RTD) perubahan tahanannya lebih linear terhadap temperatur uji tetapi koefisien lebih rendah dari thermistor dan model matematis linier.

Teori Dasar Termokopel Type K.

Tipe $\mathrm{K}$ adalah termokopel yang berbiaya murah dan umum digunakan, karena popularitasnya itu termokopel jenis ini tersedia dalam berbagai macam probe. Termokopel tipe $\mathrm{K}$ ini tersedia untuk rentang suhu di $-200{ }^{\circ}$ C sampai $+1200^{\circ}$ C. Sensitivitasnya adalah kira-kira $41 \mu \mathrm{v} /{ }^{\circ} \mathrm{C}$. Termokopel merupakan sensor suhu yang terdiri atas sepasang penghantar yang berbeda disambung las atau dileburkan bersama pada satu sisi membentuk penghantar "hotjunction" atau sambungan pengukuran yang ada ujung ujung bebasnya untuk menghubungkan dengan penghantar "coldjunction" atau sambungan referensi. Ilustrasinya dapat dilihat pada gambar dibawah ini.

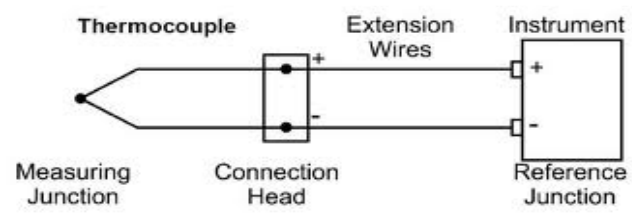

Gambar 1.4 penghantar "hot junction, cold junction".

Perbedaan suhu antara sambungan pengukuran dan sambungan referensi alat ini berfungsi sebagai termokopel dan bisa membangkitkan tegangan dc yang kecil.

Digital Temperature Controller

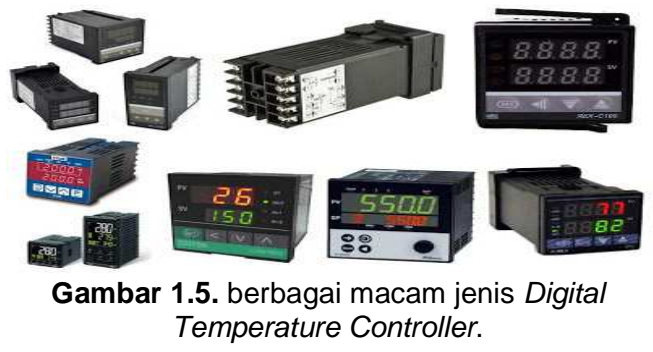

Terbacanya nilai output dari termokopel tersebut tentunya membutuhkan sebuah peralatan elektonik digital terpadu yang dinamakan Thermocouple Amplifier Digital yang lebih dikenal dikalangan teknik kelistrikan industri sebagai "Digital Temperature Controller". Digital Temperature Controller ini adalah alat yang bisa mengontrol suhu untuk mengendalikan cooler / heater sesuai dengan settingan yang diinginkan. Sama seperti prinsip kerja Digital Counter relay, Digital Thermostat ini mempunyai kontak-kontak NO / NC pada output settingnya, serta membutuhkan input power supply dalam kerjanya.

ISO/IEC17025 Laboratorium Sistem Mutu Laboratorium memiliki peran penting dalam sistem mutu di perusahaan. ISO / IEC 17025 (1) dapat digunakan sebagai standar untuk mengembangkan dan membangun sistem mutu di laboratorium serta penilaian yang dilakukan oleh klien atau pihak ketiga. Standar ini juga digunakan sebagai kriteria untuk akreditasi 
laboratorium. Edisi pertama (1999) ISO / IEC 17025 yaitu International Standar "Persyaratan Umum Kompetensi Laboratorium Pengujian dan Kalibrasi" / General Requirements for the Competence of Testing and Calibration Laboratories, dan diproduksi sebagai hasil dari pengalaman yang luas dalam penerapan ISO / IEC Guide 25 dan EN 45001, di mana keduanya itu diganti. Berisi tentang semua persyaratan bahwa laboratorium pengujian dan kalibrasi harus berkesinambungan apabila laboratorium tersebut ingin menunjukkan dalam pengoperasian sistem manajemen, secara teknis kompeten dan mampu menghasilkan data yang valid secara teknis. Persyaratan manajemen edisi pertama disebut ISO 9001:1994 dan ISO 9002:1994. Namun standar-standar ini telah digantikan oleh ISO 9001:2000, yang membuat keselarasan ISO / IEC 17025 itu diperlukan. ISO 17025 mengeluarkan edisi kedua yang dirilis pada tahun 2005 memperbaiki hal-hal yang dianggap perlu dalam ISO 9001:2000. Laboratorium pengujian dan kalibrasi yang memenuhi Standar Internasional juga dapat mempengaruhi akreditasi, karena harus beroperasi sesuai dengan ISO 9001. (Lampiran 1).

\section{METODOLOGI}

Langkah-langkah perancangan sebagai berikut:

a) Merancang dan membuat model kalibrasi pada sensor Temperatur (PT100, dan Termokopel type K) dengan metode sensor plus indikator.

b) Mengimplementasikan bentuk matematika untuk proses kalibrasi dengan metode sensor plus indikator dari metode perbandingan dari suatu pengukuran sensor Temperatur PT 100 dan Termokopel type K.

c) Sebagai langkah awal dari suatu pembuktian teori yang dikembangkan melalui tahapan model dari kalibrasi dengan metode sensor plus indikator dan dibuat simulasi pada Indicator Controller untuk sensor suhu PT100 dan Termokopel type $\mathrm{K}$. d) Alat yang diperlukan untuk Kalibrasi Temperatur berupa: Media Kalibrasi Berupa Water Bath $\left(0-100^{\circ} \mathrm{C}\right)$ dan air dingin pada heater Alat yang dikalibrasi (Indikator) pada termometer digital.

\section{Kalibrasi Termometer Digital}

Pengambilan data di Laboratorium Elektronik dan alat yang diperlukan untuk kalibrasi temperatur berupa: master kalibrasi berupa thermos es $\left(0^{\circ} \mathrm{C}\right)$ dan air mendidih $\left(100^{\circ} \mathrm{C}\right)$ pada heater, Alat yang dikalibrasi (indikator) E5EK Omron, Pedoman pelaksanaan, kalibrasi (SOP). Pelaksanaan kalibrasi dilaksanakan pada indikator E5EK Omron yang terpasang pada mesin yang mengatur temperatur misalnya mesin turing pada proses pembuatan ban. Kalibrasi harus sesuai dengan bagan alur seperti ditunjukkan pada Gambar 2.1.

Data pengukuran dan analisis set-up peralatan indikator berupa E5EK Omron digital controller. Ada 3 data pengukuran: minimal, medium, dan maksimal. Data pengukuran PT100 setelah dikalibrasi, data pengukuran PT100 setelah dikalibrasi (Gambar 2.2)

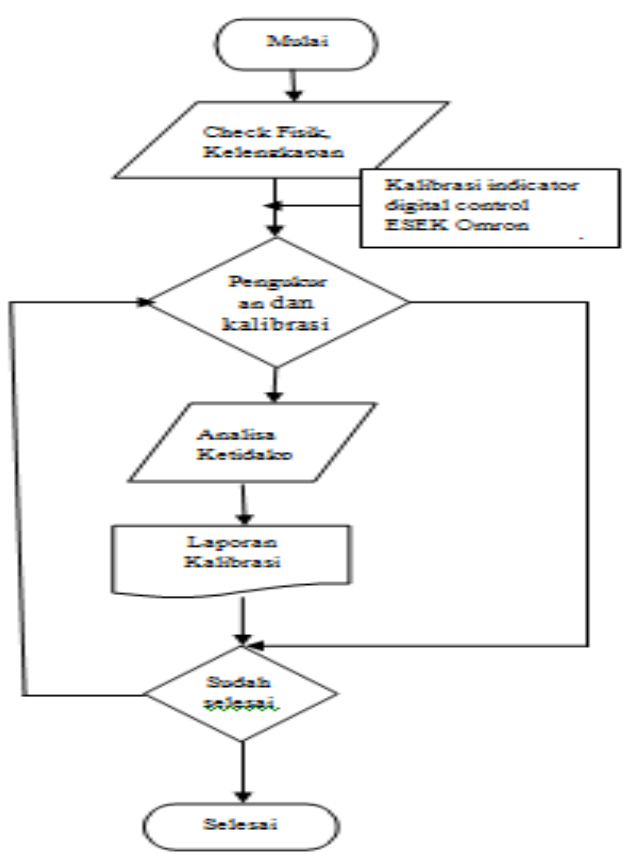

Gambar 2.1. Bagan Alur Kalibrasi. 


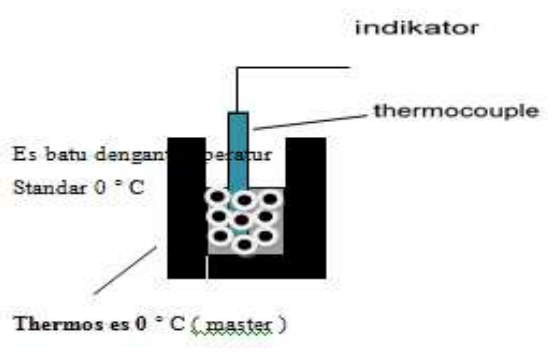

Gambar 2.2. Pengukuran Cold Junction

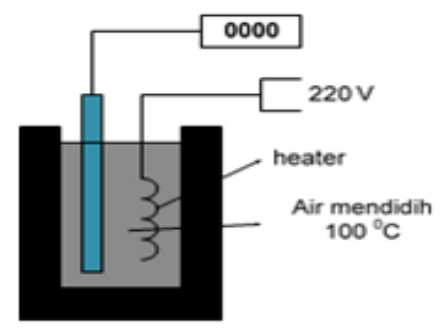

Gambar 2.3. Pengukuran Hot Junction

Perhitungan Ketidakpastian

$x=\frac{\text { air mendidih } 100^{\circ} \mathrm{C}}{\sqrt{\sum_{i-1}^{00} \frac{(x-x)}{N-1}}}=0,3^{i}$ urs $\frac{\text { usd }}{2}=0.15$

$u c=\sqrt{u s d^{2}+u m^{2}}=0,33$;

Uexp $=$ UexK $=0.65$

Dengan:

Usd = ketidakpastian standar,

Um =ketidakpastian master,

Uc =ketidakpastian gabungan,

Uexp = ketidakpastian terentang, tingkat

kepercayaan 95\% (K=2).

Dari data perbandingan dapat dibuat simulasi dengan manipulasi data pada digital controller E5EK OMRON.

\section{HASIL DAN PEMBAHASAN}

Hasil Kalibrasi dan Pengukuran pada PT100 dan Termokopel Type K Kalibrasi PT100 dan perhitungan Kalibrasi PT100
Tabel 2 Hasil Pengukuran dan Hasil Kalibrasi PT100

\begin{tabular}{|c|c|c|c|c|c|}
\hline No & $\begin{array}{l}\text { Suhwu } \\
{ }^{\circ} \mathrm{C}\end{array}$ & $\begin{array}{c}\text { Standarisas } \\
\text { PT } \\
100 . \mathrm{DIN} \\
\text { IEC } 75 \\
\Omega\end{array}$ & $\begin{array}{c}\text { Hasil } \\
\text { Kalibrasi } \\
\text { PT100 } \\
\Omega\end{array}$ & $\begin{array}{c}\text { Hasil } \\
\text { Kalibrasi } \\
\text { sendiri } \\
\Omega\end{array}$ & $\begin{array}{c}\text { Ketidakpastian } \\
\Omega\end{array}$ \\
\hline 1 & 10 & 103.9 & 103.941 & 103.8 & 0.141 \\
\hline 2 & 20 & 107.79 & 107.834 & 107.6 & 0.234 \\
\hline 3 & 30 & 111.67 & 111.717 & 111.7 & 0.017 \\
\hline 4 & 40 & 115.54 & 115.592 & 115.3 & 0.292 \\
\hline 5 & 50 & 119.4 & 119.457 & 119.3 & 0.157 \\
\hline 6 & 60 & 123.24 & 123.314 & 124 & -0.686 \\
\hline 7 & 70 & 127.07 & 127.161 & 127.7 & -0.539 \\
\hline 8 & 80 & 130.89 & 131 & 131.2 & -0.2 \\
\hline 9 & 90 & 134.7 & 134.829 & 134.6 & 0.229 \\
\hline 10 & 100 & 138.5 & 138.649 & 138.2 & 0.449 \\
\hline & \multicolumn{4}{|c|}{ Ketidakpstian Kalibrasi $\pm 0.094 \Omega$} & $0.094 \Omega$ \\
\hline
\end{tabular}

$$
\text { Rumus Usd }=\frac{\text { air mendidih } 100^{\circ} \mathrm{C}}{\sqrt{\sum_{i-1}^{00} \frac{(x-x)^{2}}{n-1}}}
$$

$U \mathrm{~m}=\frac{U s d}{2}$

$U c=\sqrt{U s d^{2}+U m^{2}}$

Uexp = Ucxk

1. Rumus Usd $=\frac{\text { air mendidih } 100{ }^{\circ} \mathrm{C}}{\sqrt{\sum_{i-1}^{00} \frac{(x-x)^{2}}{n-1}}}=0.141$

$\mathrm{Um}=\frac{U s d}{2}=\frac{0.141}{2}=0.07$

$U c=\sqrt{U s d^{2}+U m^{2}}$

$U c=\sqrt{0.141^{2}+0.07^{2}}$

$\mathrm{Uc}=0.211$

Uexp $=$ Ucxk

$$
=0.211 \times 2=0.422 \Omega
$$

2. Rumus Usd $=\frac{\text { air mendidih } 100^{\circ} \mathrm{C}}{\sqrt{\sum_{i-1}^{00} \frac{(x-x)^{2}}{n-1}}}=0.157$

$U \mathrm{~m}=\frac{U s d}{2}=\frac{0.157}{2}=0.078$

$\mathrm{Uc}=\sqrt{U s d^{2}+U m^{2}}$

Uc $=\sqrt{0.157^{2}+0.078^{2}}$

$\mathrm{Uc}=0.163$

Uexp $=$ Ucxk

$$
=0.163 \times 2=0.326 \Omega
$$

3. Rumus Usd $=\frac{\text { air mendidih } 100^{\circ} \mathrm{C}}{\sqrt{\sum_{i-1}^{00} \frac{(x-x)^{2}}{n-1}}}=0,449$

$\mathrm{Um}=\frac{U s d}{2}=\frac{0,449}{2}=0.224$

$\mathrm{Uc}=\sqrt{U s d^{2}+U m^{2}}$

$\mathrm{Uc}=\sqrt{0,449^{2}+0.224^{2}}$

$\mathrm{Uc}=0,499$

Uexp $=$ Ucxk

$$
=0,499 \times 2=0,998 \Omega
$$

Keterangan hasil tabel 2 dan pada RTD PT100.

Dari hasil pengukuran RTD PT100 dengan media air. Untuk mendapatkan suhu yang stabil dengan media air ini, maka 
disini air harus berputar/ada sirkulasi, supaya suhu pada air tersebut dapat merata kebagian paling bawah, tengah, dan atas. Hasil pengukuran pada tabel 2 membuktikan bawah pengukuran suhu $10^{\circ} \mathrm{C}$ sampai dengan $100{ }^{\circ} \mathrm{C}$, menujukan resistansi pada RTD PT100 meranjak naik setiap kenaikan suhu pada air sebesar $0.0385 \Omega / 1{ }^{\circ} \mathrm{C}$ dengan ketidakpastian sebesar $\pm 0.0094 \Omega / 10^{\circ} \mathrm{C}$ ( tabel 2 ).

Tabel 3. Data Pengukuran PT100 yang Dikalibrasi

\begin{tabular}{|c|c|c|}
\hline Suhu/Temperature & \multicolumn{2}{|c|}{$\begin{array}{c}\text { Pembacaan } \\
\text { AlatIReading }\end{array}$} \\
\hline$\left({ }^{\circ} \mathrm{C}\right)$ & $\Omega$ & $\left({ }^{\circ} \mathrm{C}\right)$ \\
\hline 10,0 & 103,941 & 10,10 \\
\hline 20,0 & 107,834 & 20,10 \\
\hline 30,0 & 111,717 & 30,11 \\
\hline 40,0 & 115,592 & 40,13 \\
\hline 50,0 & 119,457 & 50,16 \\
\hline 60,0 & 123,314 & 60,19 \\
\hline 70,0 & 127,161 & 70,23 \\
\hline 80,0 & 131,000 & 80,27 \\
\hline 90,0 & 134,829 & 90,32 \\
\hline 100,0 & 138,649 & 100,38 \\
\hline Ketidakpastian kalibrasi \\
\multicolumn{3}{|c|}{ Calibrationuncertaintv: $\pm 0.06{ }^{\circ} \mathrm{C}$} \\
\hline
\end{tabular}

Tabel 4 Data Pengukuran PT100 Dikalibrasi sendiri

\begin{tabular}{|c|c|c|c|c|c|}
\hline $\begin{array}{c}\text { Actual } \\
{ }^{\circ} \mathrm{C}\end{array}$ & $\begin{array}{c}\text { Koreksi } \\
{ }^{\circ} \mathrm{C}\end{array}$ & $\begin{array}{c}\text { Usd } \\
\Omega\end{array}$ & $\begin{array}{c}\text { Um } \\
\Omega\end{array}$ & $\begin{array}{c}\text { Uc } \\
\Omega\end{array}$ & $\begin{array}{c}\text { Ucxp } \\
\Omega\end{array}$ \\
\hline 10 & 10.422 & 0.141 & 0.0705 & 0.211 & 0.422 \\
\hline 20 & 20.494 & 0.234 & 0.117 & 0.247 & 0.494 \\
\hline 30 & 30.034 & 0.017 & 0.0085 & 0.017 & 0.034 \\
\hline 40 & 40.584 & 0.292 & 0.146 & 0.292 & 0.584 \\
\hline 50 & 50.326 & 0.157 & 0.0785 & 0.163 & 0.326 \\
\hline 60 & 58.4 & -0.686 & -0.343 & -0.8 & -1.6 \\
\hline 70 & 68.778 & -0.539 & -0.2695 & -0.611 & -1.222 \\
\hline 80 & 79.58 & -0.2 & -0.1 & -0.21 & -0.42 \\
\hline 90 & 90.484 & 0.229 & 0.1145 & 0.242 & 0.484 \\
\hline 100 & 100.898 & 0.449 & 0.2245 & 0.449 & 0.898 \\
\hline \multicolumn{5}{|c|}{ Ketiakpastian hasil pengukuran $\pm 0.6484 \Omega$} & 0.6484 \\
\end{tabular}

Dengan:

Usd = ketidakpastian standar, Um =ketidakpastian master,
Uc = ketidakpastian gabungan, Uexp = ketidakpastian terentang, tingkat kepercayaan $95 \%(\mathrm{~K}=2)$.

Tabel 5 Hasil Pengukuran dan Kalibrasi Termokopel.

\begin{tabular}{|c|c|c|c|c|c|c|}
\hline No & Suhu & $\begin{array}{l}\text { Hasil } \\
\text { Kalibrasi } \\
\text { Suhu } \\
\text { Termokopel } \\
\quad\left({ }^{\circ} \mathrm{C}\right) \\
\end{array}$ & $\begin{array}{c}\text { Hasil Kalibras } \\
\text { Termokopel } \\
\text { (volt ) }\end{array}$ & \begin{tabular}{|c} 
Hasil \\
Pengukuran \\
Termokopel \\
(volt)
\end{tabular} & \begin{tabular}{|l} 
Hasil \\
Pengukuran \\
PT100 \\
$(\Omega)$ \\
$(\Omega)$
\end{tabular} & $\begin{array}{l}\text { Koreksi } \\
\text { /ketidakpastian } \\
\text { Termokopel } \\
\text { (volt) }\end{array}$ \\
\hline 1 & 10 & 10,1 & 0,3 & 0,2 & $6,4 \Omega$ & 0,1 \\
\hline 2 & 20 & 20,1 & 0,8 & 0,7 & $5,1 \Omega$ & 0,1 \\
\hline 3 & 30 & 30,2 & 12 & 1,1 & $4,4 \Omega$ & 0,1 \\
\hline 4 & 40 & 40,2 & 1,6 & 1,5 & $3,9 \Omega$ & 0,1 \\
\hline 5 & 50 & 50,3 & 2,0 & 1,9 & $3,3 \Omega$ & 0,1 \\
\hline 6 & 60 & 60,3 & 2,4 & 2,1 & $3,1 \Omega$ & 0,3 \\
\hline 7 & 70 & 70,2 & 2,8 & 2,8 & $1,9 \Omega$ & 0 \\
\hline 8 & 80 & 80,2 & $3,2 \mathrm{v}$ & 3,2 & $1,3 \Omega$ & 0 \\
\hline 9 & 90 & 90,2 & $3,6 \mathrm{v}$ & 3,5 & $0,8 \Omega$ & 0,1 \\
\hline 10 & 100 & 100,2 & $4,1 \mathrm{v}$ & 3,9 & $0,3 \Omega$ & 0,2 \\
\hline & & $\begin{array}{c} \pm(0,7+0,06 \\
\% \text { ot })^{\circ} \mathrm{C}\end{array}$ & \multicolumn{3}{|c|}{$\begin{array}{l}\text { Jadi hasil koreksi / ketidakpastian yang di } \\
\text { dapat pada tabel di atas adalah : } 0,09 \mathrm{v}\end{array}$} & $0,09 \mathrm{~V}$ \\
\hline
\end{tabular}

1. Rumus Usd $=\frac{\text { air mendidih } 100^{\circ} \mathrm{C}}{\sqrt{\sum_{i-1}^{00} \frac{(x-x)^{2}}{n-1}}}=0.1$

$$
\begin{aligned}
& \mathrm{Um}=\frac{U s d}{2}=\frac{0.1}{2}=0.05 \\
& \mathrm{Uc}=\sqrt{U s d^{2}+U m^{2}} \\
& \mathrm{Uc}=\sqrt{0.1^{2}+0.05^{2}} \\
& \mathrm{Uc}=0.102 \\
& \text { Uexp }=\text { Ucxk } \\
& =0.102 \times 2=0.205 \Omega
\end{aligned}
$$

2. Rumus Usd $=\frac{\text { air mendidih } 100^{\circ} \mathrm{C}}{\sqrt{\sum_{i-1}^{00} \frac{(x-x)^{2}}{n-1}}}=0.1$

$$
\begin{aligned}
& U \mathrm{~m}=\frac{U s d}{2}=\frac{0.1}{2}=0.05 \\
& \mathrm{Uc}=\sqrt{U s d^{2}+U m^{2}} \\
& \mathrm{Uc}=\sqrt{0.1^{2}+0.05^{2}} \\
& \mathrm{Uc}=0.102 \\
& \text { Uexp }=\text { Ucxk } \\
& =0.102 \times 2=0.205 \Omega
\end{aligned}
$$

3. Rumus Usd $=\frac{\text { air mendidih } 100^{\circ} \mathrm{C}}{\sqrt{\sum_{i-1}^{00} \frac{(x-x)^{2}}{n-1}}}=0,09$

$$
\begin{aligned}
& \sqrt{\sum_{i-1}^{00}} \frac{(x-x)^{2}}{n-1} \\
& U \mathrm{~m}=\frac{U s d}{2}=\frac{0,09}{2}=0.045 \\
& \mathrm{Uc}=\sqrt{U s d^{2}+U m^{2}} \\
& \mathrm{Uc}=\sqrt{0,09^{2}+0.045^{2}} \\
& \mathrm{Uc}=0,092 \\
& \text { Uexp }=\text { Ucxk } \\
& =0,092 \times 2=0,184 \Omega
\end{aligned}
$$


Tabel 6. Hasil Pengukuran dan Kalibrasi Termokopel Dengan Perhitungan

\begin{tabular}{|c|c|c|c|c|c|}
\hline $\begin{array}{c}\text { Actual } \\
{ }^{\circ} \mathrm{C}\end{array}$ & $\begin{array}{c}\text { Koreksi } \\
{ }^{\circ} \mathrm{C}\end{array}$ & $\begin{array}{c}\text { Usd } \\
\Omega\end{array}$ & $\begin{array}{c}\text { Um } \\
\Omega\end{array}$ & $\begin{array}{c}\text { Uc } \\
\Omega\end{array}$ & $\begin{array}{c}\text { Ucxp } \\
\Omega\end{array}$ \\
\hline 10 & 10,1 & 0,1 & 0,05 & 0,102 & 0,204 \\
\hline 20 & 20,1 & 0,1 & 0,05 & 0,102 & 0,204 \\
\hline 30 & 30,2 & 0,1 & 0,05 & 0,102 & 0,204 \\
\hline 40 & 40,2 & 0,1 & 0,05 & 0,102 & 0,204 \\
\hline 50 & 50,3 & 0,1 & 0,05 & 0,102 & 0,204 \\
\hline 60 & 60,3 & 0,3 & 0,15 & 0.8 & 1.6 \\
\hline 70 & 70,2 & 0 & 0 & 0 & 0 \\
\hline 80 & 80,2 & 0 & 0 & 0 & 0 \\
\hline 90 & 90,2 & 0,1 & 0,05 & 0,102 & 0,204 \\
\hline 100 & 100,2 & 0,2 & 0,1 & 0,092 & 0,184 \\
\hline \multicolumn{7}{|c|}{ Ketiakpastian hasil pengukuran } \\
$\pm(0,7+0,06 \% \text { ot })^{\circ} \mathrm{C}$ & $0.6484 \Omega$ \\
\hline
\end{tabular}

Keterangan hasil tabel 6 pada Termokopel Type K.

Termokopel yang sudah di kalibarsi, sebagai acuan untuk mengukur termokopel yang belum di kalibrasi. Pengukuran Termokopel Type $\mathrm{K}$ sendiri menggunakan media air. Untuk mendapatkan suhu yang stabil dengan media air ini, maka disini air harus berputar/ada sirkulasi, supaya suhu pada air tersebut dapat merata kebagian paling bawah, tengah, dan atas. Hasil pengukuran pada tabel 6 membuktikan bawah pengukuran suhu $10^{\circ} \mathrm{C}$ sampai dengan $100{ }^{\circ} \mathrm{C}$, menujukan Volt pada Termokopel Type $\mathrm{K}$ meranjak naik setiap kenaikan suhu pada air tersebut. Menyatakan pengukuran menggunakan acuan termokopel yang sudah dikalibrasi, dengan pengukuran sendiri dengan media air, mendapatkan hasil yang mendekati hasil yang sudah dikalibrasi. Koreksi / ketidakpastian rata-rata $0.09 \mathrm{~V} /{ }^{\circ} \mathrm{C}$ ( tabel 6 ).

\section{KESIMPULAN DAN SARAN Kesimpulan}

Memegang hasil kalibrasi dari kalibrator yang terpercaya (KAN = Komite Akreditasi Nasional) sebagai bahan pembanding, dan hasil pengukurn sendiri, membuktikan bahwa untuk pengukuran suhu $10{ }^{\circ} \mathrm{C}$ sampai dengan $100{ }^{\circ} \mathrm{C}$, menunjukkan bahwa untuk RTD PT100 meranjak naik setiap kenaikan suhu pada air sebesar $0,0385 \Omega / 1{ }^{\circ} \mathrm{C}$ dengan ketidakpastian sebesar $\pm 0,094 \Omega / 10^{\circ} \mathrm{C}$ (tabel 2). Begitu juga dengan hasil kalibrasi pada termokopel Tipe $\mathrm{K}$, untuk pengukuran sendiri dengan media air, mendapatkan hasil yang mendekati hasil yang sudah dikalibrasi, yaitu koreksi / ketidakpastian rata-rata $0,09 \mathrm{~V} / 10^{\circ} \mathrm{C}$, ( tabel 6 ).

\section{Saran}

Setelah melakukan analisis dan pengukuran pada termokopel dan RTD PT100, saya mempunyai saran bagi para pembaca hasil karya saya, karena karya saya sebagian kecil dari pengujian pengujian yang ada. Dalam pengujian suatu alat apapun kita harus mengenal alat yang akan di uji dahulu, agar kita bisa memahami karaktersitik alat tersebut, setelah kita memahami alat tersebut barulah kita bisa mulai pengujian dan menganalisinya. Dan jangan lupa untuk selalu mengkalibrasi dahulu alat ukur dan alat yang akan di kalibrasi, biar mendapatkan hasil yang akurat.

Dalam menganalisi dan pengukuran tidak lupa juga untuk selalu bertanya kepada rekan, dosen, guru, bahkan dari google, agar kita mendapatkan refrensi lebih banyak lagi tentang pengkalibrasian.

\section{Daftar Pustaka}

[1] M.C. Douglas, Process Instrumentations and Controls Handbooks, MC Graw Hill International, Los Angeles, 2003, p.1356.

[2] R.K. Jain, Mechanical and Industrial Measurement, Khana Publishers, Delhi, 2002, p.805.

[3] C.T. Killian, Modern Control Technologi: Components and Systems, $2^{\text {nd }}$ ed., DelmarPublisher/ Delmar/Thomson Learning, Singapore, 2005,p.628.

[4] KAN/BSN, Pedoman Kalibrasi Multimeter Digital (DMM), Komite Akreditasi Nasional, Jakarta, 2006, DP.yy.xx, http://www.bsn.or.id, 2006.

[5] P. Dostálek, V. Vašek, J. Dolinay, WSEAS Trans. Syst. Control, 3/9 (2008) 779.

[6] H. Fang, K. Fang, International Conference on Measuring Technology and Mechatronics Automation, 3 (2010) 852. 
[7] F. Carden, R. Jedlicka, R. Henry, Telemetry System Engineering, Artech House, Norwood, MA, USA, 2002, p.596.

[8] Y.C. Lim, A.Z. Kouzani, W. Duan, A. Kaynak, IEEE/ICME International Conferenceon Complex Medical Engineering, Gold Coast, Australia, 2010, p.396.

[9] I.T. Jolliffe, Principal Component Analysis, 2nd ed., Springer-Verlag New York Inc.,New York, 2002, p.487.

[10] J.M. Vidal, P. Buhler, C. Stahl, MultiAgent Systems with Workflows, IEEE Internet. Comput. 8/1 (2004) 76. 